Geosistemy perehodnykh zon = Geosystems of Transition Zones / Геосистемы переходных зон

Content is available under the Creative Commons Attribution 4.0 International License (CC BY 4.0)

2021, vol. 5, No. 1, pp. 4-13

URL: http://journal.imgg.ru/archive.html ; https://elibrary.ru/title about.asp?id=64191

https://doi.org/10.30730/gtrz.2021.5.1.004-013

\title{
Underwater gas-hydrothermal activity within the Kuril island arc
}

Vyacheslav I. Bondarenko', https://orcid.org/0000-0002-6521-2915, vibond@list.ru

Vladimir A. Rashidov², https://orcid.org/0000-0002-5790-6829, rashidva@kscnet.ru

${ }^{1}$ Kostroma State University, Kostroma, Russia

${ }^{2}$ Institute of Volcanology and Seismology, FEB RAS, Petropavlovsk-Kamchatsky, Russia

\section{Abstract PDF ENG Резюме PDF RUS $\quad$ Full text $\underline{\text { PDF RUS }}$}

Abstract. The Kuril island arc is an important element of the Pacific transition zone, within which such modern geological processes as underwater gas-hydrothermal activity occur. The study of underwater gas-hydrothermal activity, which affects the natural environment and all life activities, has not only fundamental but also a great practical importance. The article provides a review of research studies into the underwater gas-hydrothermal activity of the Kuril island arc. New information on the manifestations of underwater gas-hydrothermal activity within this zone obtained as a result of processing, revision and analysis of materials of complex volcanological shipboard studies at the Volcanolog research vessel (1981-1991) is presented.

\section{Keywords:}

\section{underwater gas-hydrothermal activity, Kuril island arc}

For citation: Bondarenko V.I., Rashidov V.A. Underwater gas-hydrothermal activity within the Kuril island arc. Geosistemy perehodnykh zon = Geosystems of Transition Zones, 2021, 5(1), pp. 4-13. (In Russ., abstr. in Engl.). https://doi.org/10.30730/gtrz.2021.5.1.004-013

Для цитирования: Бондаренко В.И., Рашидов В.А. Подводная газо-гидротермальная активность в пределах Курильской островной дуги. Геосистемы переходных зон, 2021, 5(1), с. 4-13.

https://doi.org/10.30730/gtrz.2021.5.1.004-013

\section{References}

1. Avdeiko G.P., Krasnov S.G. 1985. Sulphide ores and their relationship to submarine volcanoes and hydrothermal waters of island arcs. Volcanology and Seismology, 4: 26-39.

2. Avdeiko G.P., Gavrilenko G.M., Chertkova L.V., Bondarenko V.I., Rashidov V.A., Guseva V.I., Mal'tseva V.I., Sazonov A.P. 1984. Submarine gas-hydrothermal activity on the northwestern slope of the Paramushir Island, the Kurile. Volcanology and Seismology, 6: 61-81.

3. Bezrukov P.L., Zenkevich N.L., Kanaev V.F., Udincev G.B. 1958. [Submarine mountains and volcanoes of the Kuril island arc]. Trudy Laboratorii vulkanologii [Proceedings of the Laboratory of Volcanology], 13: 71-88. (In Russ.).

4. Blokh Yu.I., Bondarenko V.I., Dolgal' A.S., Novikova P.N., Petrova V.V., Pilipenko O.V., Rashidov V.A., Trusov A.A. 2020. [Complex geological and geophysical studies of submarine volcanoes of the Central and Southern Kuriles]. In: Questions of theory and practice of geological interpretation of gravitational, magnetic and electric fields: Proceedings of the 47th session of the International Scientific Seminar named after D.G. Uspensky - V.N. Strakhov, Voronezh, January 27-30, 2020. Voronezh: Scientific Book, p. 41-44. (In Russ.).

5. Blokh Yu.I., Bondarenko V.I., Dolgal' A.S., Novikova P.N., Petrova V.V., Pilipenko O.V., Rashidov V.A., Trusov A.A. 2020. [New data on the structure of submarine volcanoes of the Central and Southern Kuriles]. In: IX International conference "Marine Research and Education» (MARESEDU-2020)", 3(3): 482-485. (In Russ.).

6. Bondarenko V.I. 1986. The structure of the Kraternaya volcanic depression, Kuril Islands: Seismoacoustic surveys. Volcanology and Seismology, 5: 96-101.

7. Bondarenko V.I. 1990. Stroenie podvodnyh kal'der po dannym sejsmoakusticheskogo profilirovaniya (na primere Kuril'skoj ostrovnoj dugi) [The structure of submarine calderas according to the data of seismoacoustic profiling (by the example of the Kuril island arc)]: [Extended abstract of candidate's dissertation in Geology and Mineralogy]. Moscow, 24 p. (In Russ.).

8. Bondarenko V.I. 2015. [Structure and forming history of the Ushishir volcanic massif (Central Kurile)]. In: Geology of seas and oceans: Materials of the XIX International scientific conference (School) on marine geology. Moscow: GEOS, vol. 5: 38-42. (In Russ.).

9. Bondarenko V.I., Nadezhnyi A.M. 1987. Acoustic inhomogeneities of sedimentary cover in the area of submarine hydrothermal vent near Paramushir Island. Volcanology and Seismology, 2: 100-104.

10. Bondarenko V.I., Rashidov V.A. 2003. On probable submarine volcanic activity in region Chernye Brat'ya islands (Kurile Islands). Vestnik KRAUNTS. Nauki o Zemle = Bull. of KRAESC. Earth Sciences, 2: 80-88. (In Russ.).

11. Bondarenko V.I., Rashidov V.A. 2006. A submarine volcanic zone to the West of Paramushir Island (Kuril island arc). Vestnik KRAUNTs. Nauki o Zemle = Bull. of KRAESC. Earth Sciences, 2(8): 69-85. (In Russ.). 
12. Bondarenko V.I., Rashidov V.A. 2011. [Appearance of gas hydrate and mud volcanism in area of Bussol' strait (Kurile island arc)]. In: Geology of seas and oceans: Materials of the XIX International scientific conference (School) on marine geology, Moscow, November 14-18, 2011. Moscow: GEOS, vol. 5: 38-42. (In Russ.).

13. Bondarenko V.I., Rashidov V.A. 2018a. The structure of the Ushishir Volcanic Massif, Central Kurils. J. of Volcanology and Seismology, 12(1): 16-33. https://doi.org/10.1134/s0742046318010025

14. Bondarenko V.I., Rashidov V.A. 2018b. [Underwater volcanic activity on the Okhotsk side of the Kuril island arc]. Actual Problems of Oil and Gas, 4(23). (In Russ.). https://doi.org/10.29222/ipng.2078-5712.2018-23.art51

15. Bondarenko V.I., Rashidov V.A. 2019. [Submarine Caldera of Prostor Bay, Iturup Island, Kurile islands]. In: Geology of seas and oceans: Materials of the XXIII International scientific conference (School) on marine geology, Moscow, November 18-22, 2019. Moscow: GEOS, vol. 5: 54-57. (In Russ.).

16. Gavrilenko G.M. 1987. [Submarine volcanic and hydrothermal activity as a source of metals in Island-Arc ferromanganese deposits]. Vladivostok: Dalnauka, 165 p. (In Russ.).

17. Ginzburg G.D., Solovyov V.A. 1994. [Submarine gas hydrates]. St. Petersburg: All-Russia Research Institute for Geology and Mineral Resources of the World Ocean "VNIIOkeangeologiya", 199 p. (In Russ.).

18. Zonenshain L.P., Murdmaa I.O., Baranov B.V., Kuznetsov A.P., Kuzin V.C., Kuz'min M.I., Avdeiko G.P., Stunzhas P.A., Lukashin V.N., Barash M.C., Valyashko G.M., Demin L.L. 1987. [Underwater gas source in the Sea of Okhotsk to the west from Paramushir Island]. Oceanology, 27(5): 795-800. (In Russ.).

19. Kozlov D.N. 2015. Crater Lakes of the Kuril Islands. Yuzhno-Sakhalinsk: Sakhalin. obl. kraevedch. muzey; In-t morskoy geologii i geofiziki DVO RAN, 112 p. (In Russ.).

20. Lomtev V.L. 2014.To the structure and cenozoic cover gas presence of the Northern Mid-Kuril trough (by seismic continuous data). Deep Oil, 2(6): 953-968. (In Russ.). URL: http://journal.deepoil.ru/images/stories/docs/DO-2-6-2014/6_Lomtev_2-62014.pdf

21. Lomtev V.L., Patrikeev V.N. 2012. New peculiarities in the structure of Northern Mid-Kuril Trough (based on seimic continuous data). Vestnik KRAUNTs. Nauki o Zemle = Bull. of KRAESC. Earth Sciences, 2(20): 59-70. (In Russ.).

22. Mel'nichenko Yu.I., Kazanskiy B.A., Obzhirov A.I. 1990. [Hydroacoustic effects during echo sounding of the floor of marine basins]. In: Novye dannye po geomorfologii i geologii zapadnoy chasti Tikhogo okeana [New data on geomorphology and geology of the Western Pacific]. Vladivostok: DVO AN SSSR, p. 75-89. (In Russ.).

23. Nadezhnyi A.M., Bondarenko V.I. 1989. Gas gidrates in the Kamchatka-Paramushir part of the Sea of Okhotsk. Doklady Earth Sciences, 306(5): 1192-1195. (In Russ.).

24. Obzhirov A.I. Astakhova N.V., Lipkina M.I., Vereshchagina O.F., Mishukova G.I., Sorochinskaya A.V., Yugay I.G. 1999. [Gasgeochemical zoning and floor mineral association of the Sea of Okhotsk]. Vladivostok: Dalnauka, 183 p. (In Russ.).

25. Podvodnyy vulkanizm i zonal'nost' Kuril'skoy ostrovnoy dugi [Submarine volcanism and zonation of the Kuril island arc] (Ed. Yu.M. Pushcharovskiy). 1992. Moscow: Nauka, 528 p. (In Russ.).

26. Rashidov V.A. 2010. Geomagnitnye issledovaniya pri izuchenii podvodnyh vulkanov ostrovnyh dug i okrainnyh morej zapadnoj chasti Tihogo okeana [Geomagnetic investigations during the study of submarine volcanoes at island arcs and in marginal seas of the Western Pacific]: [Extended abstract of candidate's dissertation in Engineering]. Petropavlovsk-Kamchatsky, $27 \mathrm{p}$. (In Russ.).

27. Rashidov V.A. 2013.Taketomi subordinate volcano, Atlasov Island, the Kurile island arc. Geophysical Processes and Biosphere, 12(1): 5-13. (In Russ.).

28. Rashidov V.A., Bondarenko V.I. 2004. Geophysical studies of Krylatka submarine volcano, Kuril Islands. Journal of Volcanology and Seismology, 4: 65-76.

29. Gaedicke C., Baranov B.V., Obzhirov A.I. Lelikov E.P., Belykh I.N., Basov E.I. 1997. Seismic stratigraphy, BSR distribution and venting of metan-rich fluids west off Paramushir and Onekotan Islands, northern Kurils. Marine Geology, 136: $259-276$. https://doi.org/10.1016/s0025-3227(96)00067-9

30. Tanakadate H. 1934. Volcanic activity in Japan during the period between June 1931 and June 1934. Japanese J. Of Astronomy and Geophysics, 12: 89-108. 